\title{
ROLE ATTAINMENT IBU DALAM PEMBERIAN ASI PADA BAYI IKTERUS DI PAVILIYUN ANGGREK RSUD KABUPATEN JOMBANG
}

\author{
Role Attainment Of Mother in Giving Breastfeed \\ To The Jaundice Baby In Anggrek \\ Pavillion Of RSUD Jombang
}

\author{
Ani Sulistyowati", Ririn Probowati, Rodiyah \\ Stikes Pemkab Jombang \\ Email : anisulistyograceta@gmail.com
}

\begin{abstract}
ABSTRAK
Masih banyak bayi yang dilahirkan mengalami ikterus yang fisiologis. Ibu post parfum dengan bayi ikterus diharapkan dapat memberikan pengasuhan untuk pencapaian role attainment dalam pemberian ASI untuk penurunan derajat ikterus pada bayi. Penelitian ini bertujuan untuk mengidentifikasi role attainment ibu dalam pemberian ASI pada bayi ikterus sebelum dan sesudah dilakukan pendidikan kesehatan serta menganalis pengaruh pendidikan kesehatan dengan pencapaian role attainment dalam pemberian ASI.

Desain penelitian menggunakan metode pra eksperimen dengan jenis one group pretest dan post test dengan populasi semua ibu yang mempunyai bayi ikterus fisiologis di paviliyun anggrek Jombang pada bulan juni 2017. Besar sample 25 responden dipilih dengan teknik random sampling secara sistematis. Instrumen menggunakan lembar observasi. variable penelitian yaitu pendidikan kesehatan, role attainment ibu dalam kompetensi pemberian ASI. uji analitik uji Wilcoxon dengan nilai $<\alpha(0,05)$.

Hasil penelitian yang didapatkan hampir seluruhnya responden (76\%) sebelum dilakukan pendidikan kesehatan role attainment dalam kategori cukup. Dan setelah dilakukan pendidikan kesehatan role attainment ibu dalam kategori baik $(72 \%)$. Hasil uji analisis didapatkan nilai $\mathfrak{p}$ value $=0,001$, dengan nilai $\mathfrak{p}$ value $<\alpha(0,464)$. Terdapat tingkat keeratan cukup antara pendidikan kesehatan dengan role attainment ibu.

Untuk pencapaian role attainment ibu dibutuhkan pendidikan kesehatan dengan sebuah modul, dan ada faktor-faktor lain yang mempengaruhi role attainment ibu antara lain factor ayah, ibu dan bayi.
\end{abstract}

Kata kunci : Role Attainment, bayi ikterus.

\section{ABSTRACT}

Many jaundice baby who born in physiological condition. Post partum mother is expected to give the parenting to achieve the role attainment in giving breastfeed to decrease the level of baby's jaundice. The purpose of this study is to identify the role attainment in giving breastfeed to the jaundice baby before and after giving the health education and analyzed the influence of health education of the achievement of role attainment in giving the breastfeed.

The design of study used pre experiment method with one group pretest and post test. The populations were all mothers who had jaundice baby in anggrek pavilion of RSUD Jombang at June 2017. Samples were 25 respondents used random sampling technique systematically. The instrument used observation sheet. The variables were health education, mother's role attainment in the ability of giving breastfeed. Statistical test used wilcoxon test with value $<\alpha(0,05)$.

The result of this study obtained mostly all respondents (76\%) before hold health education of role attainment in enough categories. After giving health education, role attainment was in good category (72\%). The result of analysis test gained $p$ valur $=0,001$. With $p$ value $<\alpha(0,464)$, Had enough correlation between health education and role attainment of mother.

To achieve role attainment of mother was needed health education with a module, and the other factors that influenced mother's role attainment such as father, mother and baby.

Keywords: Role Attainment, Jaundice baby. 


\section{PENDAHULUAN}

Pada bayi yang baru lahir normal sering terjadi ikterus neonatorum fisiologis atau patologis yang berdampak pada pertumbuhan dan perkembangan bayi. Iketerus adalah warna kuning pada kulit dan selaput mata bayi ${ }^{1}$.Dikarenakan kulit tubuhnya berwarna kuning, membuat bayi harus mendapatkan perawatan di rumah sakit. Perawatan bayi ikterus tidak hanya dilakukan oleh tenaga kesehatan yang ada di rumah sakit tetapi role attainment ibu juga harus ada.

Pada bayi baru lahir dengan ikterus mengalami kegagalan dalam masa transisi yaitu pada sistem metabolismenya. Ikterus pada bayi baru lahir pada minggu pertama terjadi pada $60 \%$ bayi cukup bulan dan $80 \%$ bayi kurang bulan. Hal ini adalah keadaan yang fisiologis. Walaupun demikian, sebagian bayi akan mengalami ikterus yang berat sehingga memerlukan pemeriksaan dan tata laksana yang benar untuk mencegah kesakitan dan kematian ${ }^{2}$

Ikterus adalah warna kuning yang tampak pada kulit dan mukosa karena peningkatan bilirubin. Biasanya mulai tampak pada kadar bilirubin serum > $5 \mathrm{mg} / \mathrm{dl}$. Ikterus biasanya fisiologis, namun pada sebagian kasus dapat menyebabkan masalah: yang paling ditakuti adalah ensefalopati bilirubin. ${ }^{3}$ Bayi yang menderita ensefalopati bilirubin/kern ikterus akan mengalami gangguan proses pertumbuhan dan perkembangan seperti retardasi mental, serebral palsy dan gangguan pendengaran ${ }^{4}$. Sedangkan menurut ${ }^{5}$. icterus adalah kondisi munculnya warna kuning di kulit dan selaput mata pada bayi baru lahir karena adanya bilirubin pada kulit dan selaput mata sebagai akibat peningkatan bilirubin dalam darah.

Kejadian ikterus di Amerika serikat, sebanyak 65\% menderita ikterus dalam minggu pertama kehidupannya. Di malaysia hasil survei pada tahun 2010 di rumah sakit pemerintah dan pusat kesehatan dibawah Departemen Kesehatan mendapatkan 75\% bayi baru lahir menderita ikterus dalam minggu pertama kehidupannya, Di Indonesia, insiden ikterus neonatorum pada bayi cukup bulan dibeberapa Rumah Sakit pendidikan antara lain RSCM, RS Dr.Sardjito, RS Dr.
Soetomo, RS Dr. Kariadi bervariasi dari 13,7\% hingga $85 \%$ (Depkes, 2004).

Pada bayi baru lahir yang mengalami ikterus dapat disebabkan salah satunya adalah kurangnya pemberian ASI .6 Sedangkan menurut review penelitian menjelaskan bahwa pemberian ASI yang tidak adekuat menyebabkan dehidrasi, yang dipercaya sebagai penyebab ikterus neonatorum. ASI adalah makanan terbaik untuk seorang bayi yang belum bisa mencerna jenis makanan apapun sampai dengan usia 6 bulan. ASI memiliki banyak manfaat untuk bayi yang berguna untuk proses tumbuh kembangnya. Selain itu ASI terbukti dapat mempercepat ekskresi bilirubin melalui mekonium dan penurunan absorsi bilirubin di usus. ${ }^{7}$ Yang menjadi permasalahan adalah sebagian ibu belum mengetahui manfaat memberikan ASI pada bayinya yang disebabkan kurangnya pengetahuan, mereka cenderung ketakutan dan tidak percaya diri ${ }^{8}$. Selain itu ibu juga belum mampu menyusui dengan tehnik yang benar. Role attainment ibu dalam memberikan ASI pada bayinya sangatlah penting untuk pertumbuhan dan perkembangan bayi.

Salah satu program pelayanan kesehatan neonatal adalah pemantauan kejadian ikterus neonatal. Fokus tindakan pada program ini adalah melakukan deteksi dini dengan melihat munculnya warna kuning pada kulit bayi dan mendorong untuk terus memberikan ASI ${ }^{9}$. Praktek pemberian ASI berhubungan dengan manajemen menyusui optimal, yaitu tindakan pemberian ASI pada bayi yang memadai, meliputi : manajemen menyusui optimal 10-12 kali per hari tanpa pemberian air atau yang lain, menyusui dengan posisi yang benar sehingga dapat dipastikan transfer ASI secara efektif.

Angka kejadian icterus di ruang Paviliyun Anggrek RSUD Jombang dapat dilihat dalam tabel berikut: 
Tabel 1 Angka kejadian icterus tahun 2015 dan 2016.

\begin{tabular}{cclccc}
\hline NO & Tahun & Usia gestasi & Kadar bilirubin & Jumlah pasien & $\%$ \\
\hline 1 & 2015 & Cukup bulan & $12 \mathrm{mg} / \mathrm{dl}$ & 70 & $60 \%$ \\
& & Kurang bulan & $10 \mathrm{mg} / \mathrm{dl}$ & 50 & $75 \%$ \\
\multirow{2}{*}{2} & \multirow{2}{*}{2016} & Cukup bulan & $12 \mathrm{mg} / \mathrm{dl}$ & 53 & $65 \%$ \\
& & Kurang bulan & $10 \mathrm{mg} / \mathrm{dl}$ & 69 & $80 \%$ \\
\hline
\end{tabular}

Sumber : Rekam medis RSUD Jombang

Pada bayi dengan icterus sangat diperlukan perawatan khusus karena ibu harus mengerti baik tanda atau gejala bila terjadi perubahan yang patologis. Selain itu promosi dan dukungan Pemberian asi secara kontinyu atau terus menerus, dengan intake yang memadai sangat diperlukan. Maka dari itu Role attainment ibu dalam hal pemberian asi sangat penting untuk mencegah terjadinya icterus. Oleh karena itu, setiap ibu yang memiliki bayi memerlukan pengetahuan, sikap dan ketrampilan yang benar serta kepercayaan diri yang tinggi tentang hal tersebut.

Konsep Ramona T. Mercer: Maternal Role Attainment-Becoming a Mother mengembangkan salah satu model konseptual keperawatan yang mendasari keperawatan maternitas yaitu model Maternal Role Attainment-Becoming a mother. Fokus utama dari teori ini adalah gambaran proses pencapaian Role attainment ibu dan proses menjadi seorang ibu dengan berbagai asumsi yang mendasari.$^{10}$

Sebagai upaya dalam mengevaluasi role Attainment ibu dalam memberikan asi pada bayi dengan icterus dapat dilakukan dengan pendekatan Self Efficasy berbasis teori Becoming a Mother. Role Attainment dalam kompetensi pencapaian peran ibu ( cara menyusui, memerah ASI, dan perawatan payudara). Dalam melakukan kegiatan pencapaian peran ibu dalam memberikan ASI pada bayi icterus dapat dilakukan melalui verbal persuasion yaitu mempengaruhi secara verbal melalui pendidikan dengan keterlibatan dan penilaian secara langsung yang diberikan pada individu bahwa ibu mempunyai kemampuan untuk mencapai tujuan yaitu dapat memberikan ASI dengan baik dan benar pada bayi dengan icterus.

Studi pendahuluan yang dilakukan peneliti di Rumah Sakit Umum Daerah (RSUD) Jombang pada bulan Maret 2017 menunjukkan kejadian bayi lahir dengan ikterus sebesar $65 \%$. Selama perawatan di rumah sakit, keikutsertaan ibu dalam perawatan bayi masih rendah, sebagian besar hanya memberikan asi perah. Untuk pemberian ASI dilakukan dengan sendok atau slang orogastrik. Tetapi ada sebagian ibu yang langsung meneteki bayinya. Literatur yang berhubungan dengan program intervensi keperawatan pada orang tua bayi ikterus masih terbatas. Oleh karena itu peneliti tertarik untuk melakukan penelitian tentang adanya hubungan antara Role attainment ibu dalam pemberian ASI pada bayi ikterus.

Tugas penting perawat adalah menyusun intervensi, salah satunya adalah menggunakan modul. Isi dari modul meliputi cara menyusui, cara memerah ASI dan cara perawatan payudara. Modul berguna sebagai panduan agar orang tua dapat melakukan perawatan mandiri. Mengoptimalkan peran ibu selama perawatan di rumah sakit sangat penting. Salah satu landasannya adalah membantu menyiapkan ibu dari bayi ikterus agar dapat memberikan ASI pada bayinya secara optimal dengan menggunakan model keperawatan Mercer.

\section{METODE PENELITIAN}

Desain penelitian dalam penelitian ini adalah pra eksperimen dengan metode one group pretest post test desain. Populasi dalam penelitian ini adalah adalah semua ibu yang mempunyai bayi ikterus di paviliyun anggrek RSUD Kabupaten Jombang pada bulan juni 2017. Sampel dalam penelitian ini adalah sebagian ibu yang mempunyai bayi ikterus fisiologis dan tanpa komplikasi di ruang anggrek RSUD jombang yang memenuhi atau mewakili populasi. Sampel diambil dengan memenuhi kriteria inklusi dan eksklusi.

Kriteria inklusi dari penelitian ini adalah ibu yang kooperatif, usia bayi 0-7 hari dan ibu dengan bayi ikterus fisiologis. 
Sedangkan kriteria eksklusi dari penelitian ini adalah ibu Kesadaran umum ibu terganggu ditunjukkan dengan GCS <15

Ibu mempunyai keterbatasan fisik berupa kelainan panca indra, bayi lahir dengan kelainan kongenital

Jumlah sampel pada penelitian ini adalah 25 orang ibu yang mempunyai bayi dengan ikterus.Teknik sampling yang digunakan dalam penelitian ini adalah random sampling secara sistematis. Variabel independen pada penelitian ini adalah pendidikan kesehatan.Variabel dependen pada penelitian ini adalah role attainment ibu.
Teknik Pengumpulan data dalam penelitian ini adalah menggunakan lembar observasi yang berisi tentang kompetensi dalam pemberian ASI dengan jumlah 21 pernyataan. Analisa data pada penelitian ini menggunakan uji statistik wilcoxon.

\section{HASIL PENELITIAN}

Hasil penelitian yang diperoleh dalam penelitian role attainment ibu dalam pemberian ASI pada bayi ikterus di paviliyun anggrek RSUD Jombang sebagai berikut:

Tabel 2 Distribusi Karakteristik Umum Responden di paviliyun anggrek RSUD Kabupaten Jombang

\begin{tabular}{|c|c|c|c|}
\hline No & Karakteristik Umum & f & $(\%)$ \\
\hline \multirow[t]{4}{*}{1} & Usia & & \\
\hline & $<20$ tahun & 1 & 4 \\
\hline & $20-35$ tahun & 21 & 84 \\
\hline & $>35$ tahun & 3 & 12 \\
\hline \multirow[t]{4}{*}{2} & Pendidikan & & \\
\hline & Dasar & 2 & 8 \\
\hline & Menengah & 22 & 88 \\
\hline & Tinggi & 1 & 4 \\
\hline \multirow[t]{3}{*}{3} & Pekerjaan & & \\
\hline & bekerja & 3 & 12 \\
\hline & tidak bekerja & 22 & 88 \\
\hline \multirow[t]{3}{*}{4} & Informasi & & \\
\hline & Pernah & 25 & 100 \\
\hline & Belum pernah & - & - \\
\hline \multirow[t]{5}{*}{5} & Sumber informasi & & \\
\hline & Nakes & 21 & 84 \\
\hline & Media & 1 & 4 \\
\hline & tetangga & 3 & 12 \\
\hline & Total & 25 & 100 \\
\hline
\end{tabular}

Sumber : Data Primer 2017

Berdasarkan tabel 1 menunjukkan bahwa responden yang berusia 20-35 tahun sejumlah 21 responden, responden berpendidikan menengah sejumlah 22 responden, sebanyak 22

responden $(88 \%)$ tidak bekerja, sejumlah 25 responden $(100 \%)$ pernah mendapatkan informasi Selain itu didapatkan hasil bahwa sejumlah 21 responden (84\%) memperoleh info

Tabel 3 Distribusi Karakteristik Khusus Responden di paviliyun anggrek RSUD Kabupaten Jombang

\begin{tabular}{lcc}
\hline Karakteristik role attainment sebelm di beri penkes & $\mathrm{f}$ & $(\%)$ \\
\hline Cukup & 19 & 76 \\
Baik & 6 & 24 \\
& & \\
\hline Total & 25 & 100
\end{tabular}


Tabel 4 Distribusi Karakteristik Khusus Responden di paviliyun anggrek RSUD Kabupaten Jombang

\begin{tabular}{lcc}
\hline Karakteristik role attainment sesudah di beri penkes & $\mathrm{f}$ & $(\%)$ \\
\hline Cukup & 7 & 28 \\
Baik & 18 & 72 \\
\hline Total & 25 & 100 \\
\hline
\end{tabular}

Sumber : Data Primer 2017

Tabel 5 Tabulasi Silang antara role attainment ibu sebelum dan sesudah diberi penkes

\begin{tabular}{|c|c|c|c|c|c|c|c|}
\hline \multirow{3}{*}{ No } & \multirow{3}{*}{ Role Attaiment Sebelum } & \multicolumn{4}{|c|}{ Role attainment sesudah } & \multirow{2}{*}{\multicolumn{2}{|c|}{ Total }} \\
\hline & & Cukup & & Baik & & & \\
\hline & & f & $\%$ & f & $\%$ & f & $\%$ \\
\hline 1 & Cukup & 7 & 28,0 & 12 & 48,0 & 19 & 76,0 \\
\hline 2 & Baik & 0 & 0,0 & 6 & 24,0 & 6 & 24,0 \\
\hline Total & & 7 & 28,0 & 18 & 72,0 & 25 & 100,0 \\
\hline
\end{tabular}

Sumber : Data Primer 2017

Hasil penelitian menunjukkan bahwa hampir seluruhnya responden yang dilakukan pendidikan kesehatan sejumlah 18 responden $(72 \%)$ role attainment ibu dalam kategori baik.

\section{PEMBAHASAN}

Role Attainment Ibu sebelum diberikan pendidikan kesehatanBerdasarkan tabel 4.6 sebagian besar role attainment ibu cukup (76\%) dan berusia 20-35 tahun. Umur adalah tingkat kedewasaan sesorang yang dilihat dari kapan orang tersebut berulang tahun. Semakin matang usia responden semakin mudah menerima menyerap informasi dan tidak gampang terpengaruh dengan sikap orang lain. Pada umumnya individu cenderung mempunyai sikap yang konformis atau searah dengan sikap orang yang dianggapnya penting. 11 seseorang dengan mudah menerima informasi dan melakukan perubahan. Terjadi perubahan Role Attainment dari cukup menjadi baik. Hal ini menunjukkan adanya peningkatan pengetahuan dan ketrampilan dalam pemberian ASI pada bayi icterus setelah dilakukan pendidikan kesehatan. Pada usia ini seseorang dianggap cukup mampu untuk membuat keputusan penting, dalam hal ini adalah memberikan ASI pada anak yang dilahirkan.

Berdasarkan tabel 4.2 sebagian besar responden berpendidikan menengah. Permasalahan Role Attainment ibu pada pemberian ASI berhubungan dengan tingkat pendidikan. Teori yang dikemukakan oleh. 12 bahwa semakin tinggi pendidikan seseorang maka semakin mudah dalam menerima informasi sehingga semakin banyak pilar pengetahuan yang dimiliki. Tingkat pengetahuan dan pendidikan yang rendah akan membuat seseorang sulit menerima informasi dan melakukan perubahan. Tetapi dengan pendidikan kesehatan yang diberikan secara intensif sangat membantu ibu dalam mengenal dan mengatasi masalah yang terjadi pada bayinya.

Identifikasi Role Attainment sesudah dilakukan pendidikan kesehatan.

Berdasarkan tabel 4.7 menunjukkan Role Attainment ibu adalah baik (48\%) setelah dilakukan pendidikan kesehatan. Sedangkan menurut (wafid Iqbal \& Nurul C, 2009) pendidikan kesehatan adalah proses perubahan perilaku yang dinamis dimana perubahan tersebut bukan sekedar proses transfer materi atau teori dari seseorang ke orang lain dan pula seperangkat prosedur, tetapi perubahan tersebut terjadi karena adanya kesadaran dari dalam diri individu, kelompok, atau masyarakat sendiri.

Pendidikan kesehatan sangat penting untuk mengubah perilaku yang tidak benar/ sehat menjadi benar. Tujuan tersebut dapat dicapai dengan anggapan bahwa manusia selalu dapat belajar dan berubah sehingga role attainment menjadi baik.

Role attainment ibu dalam kompetensi pemberian ASI pada bayi icterus sangat diperlukan untuk menurunkan derajat icterus pada bayi. Setelah diberikan Pendidikan kesehatan diharapkan role attainment ibu meningkat.

Pengaruh pendidikan kesehatan dengan role attainment ibu berdasarkan tabel 4.8 menunjukkan bahwa ada pengaruh pendidikan kesehatan terhadap Role Attainment ibu dalam 
pemberian ASI pada bayi yang awalnya cukup menjadi baik. Berdasarkan tabel 4.9 hasil analisa melalui uji statistik wilcoxon menunjukkan bahwa nilai $\rho(0,001)<(\alpha)$ 0,05 . Hal ini diartikan bahwa data Ho ditolak dan $\mathrm{H}_{1}$ diterima, yang berarti bahwa ada perubahan Role Attainment ibu dalam pemberian ASI pada bayi icterus sebelum dan sesudah dilakukan pendidikan kesehatan dengan nilai korelasi 0,464 yang terletak antara 0,400-0,599 dengan tingkat keeratan cukup, yang artinya role attainment ibu meningkat tidak hanya melalui Pendidikan kesehatan saja tetapi ada faktor lain yang bisa mempengaruhi.

Teori keperawatan yang digunakan dalam penelitian ini adalah Maternal Role Attainment dari Ramona T Mercer. Terdapat 3 lingkaran yang mempengaruhi pencapaian peran ibu dan salah satunya yakni lingkaran mikrosistem. Terdapat beberapa komponen yang ada dilingkaran mikrosistem antara lain fungsi keluarga, hubungan ibu-ayah, dukungan social, status ekonomi, kepercayaan keluarga, dan stressor. Dalam hal ini interaksi antara ibu, ayah dan bayi sebagai sentral interaksi yang tinggal dalam satu lingkungan.

Untuk pencapaian peran ibu dalam kompetensi pemberian ASI pada bayi icterus seorang ibu diharuskan memahami proses menyusui. Proses menyusui merupakan proses pemberian ASI kepada bayi dari payudara ibu. Menyusui merupakan proses yang menyenangkan sekaligus sangat menenangkan bagi sang bayi disinilah letak kasih saying yang sesungguhnya.

\section{KESIMPULAN}

Hasil penelitian tentang Role Attainment ibu dalam pemberian ASI di paviliyun Anggrek RSUD Jombang pada bayi ikterus dapat disimpulkan sebagai berikut :

Dari jumlah total 25 responden sebelum diberikan pendidikan kesehatan tentang pemberian ASI pada bayi icterus (cara menyusui yang benar, cara memerah ASI dan cara perawatan payudara) mempunyai Role Attainment dengan kriteria cukup $(63,2 \%)$

Setelah dilakukan pendidikan kesehatan dari jumlah total 25 responden, hampir seluruh responden yaitu 12 . responden $(48,0 \%)$ mempunyai Role Attainment dengan kriteria Baik.
Adanya hubungan Pendidikan kesehatan tentang pemberian ASI (cara menyusui yang benar, cara memerah ASI dan cara perawatan payudara) melalui pemberian modul terhadap peningkatan Role Attainment ibu demgan tingkat keeretan cukup.

Adanya faktor faktor lain yang mempengaruhi pencapaian role attainment ibu diantaranya adalah ayah, ibu dan bayi itu sendiri.

\section{DAFTAR PUSTAKA}

prawirohardjo,2008 Buku Acuan Pelayanan Kesehatan maternal dan neonatal. Jakarta : yayasan Bina Pustaka.

Suradi \& Letupeirissa, 2013

Depkes RI. 2004. Kebijakan Departemen Kesehatan tentang peningkatan pemberian ASI. Jakarta

Dennery, P. A., Seidmen 2001 Neonatal Bilirubin

wong et al, 2008. Buku Ajar Keperawatan Pediatrik. Volume 1,Jakarta :EGC

Roesli U. 2012 Pelatihan 40 jam Breast Feeading counseling course.WHO DAN UNICEF. Indonesia Breast Feeding center.

Gourley, Li, Kremer, \& Kosorok, 2005. A controlled, Randomized, Double blind trial of profilaksis joundisce Among Breastfed Newborn. Pediatric; vol. 166:2

Dian,2004. Pentingnya mengatur jarak kehamilan (jurnal elektronik ). $\{$ diakses $\} \quad 16 \quad$ februari 2015 :http://www.bkkbn.go.id.

KNPP RI. Pemberdayaan Perempuan Dalam Peningkatan Pemberian ASI. Jakarta: Kemenkes RI; 2008.

MR. Alligood, Tomey, 2006. Nursing theoritis and their work, Edisi 7, Mosby Inc St Louis Missouri.

Azwar, 2011.Sikap Manusia Teori dan pengukurannya,Yogyakarta:Pustaka Pelajar

Notoatmojo,2010. Metodologi Penelitia Kesehatan. Jakarta : Rineka Cipta. 
wafid Iqbal \& Nurul C, 2009. Promosi

Kesehata Edisi pertama, Yogyakarta;
Graha Ilmu, 2007. 